\title{
MICROBIOLOGICAL QUALITY OF GOAT MILK PRODUCED ON ALAGOAS STATE, BRAZIL
}

CELESTINO, Erica Guedes ${ }^{1}$

SANTOS, Micheline Thaís dos ${ }^{2}$

SILVA, Sybelle Georgia Mesquita da ${ }^{1}$ SANTOS, Tania Marta Carvalho dos ${ }^{1}$ ALVES, Elizabeth Simões do Amaral ${ }^{1}$ MELO, Petrônio Azevedo de ${ }^{1}$ MELO, Breno Araújo de ${ }^{1}$

SUMMARY: The objective of this study was to verify the microbiological quality of raw and pasteurized goat milk and produced in Alagoas state, Brazil. Was carried out three interval collect of pasteurized and raw milk and the samples taken to the laboratory. All samples were subjected to aerobic mesophilic microorganisms counting, psychrotrophic microorganisms, determination of the most probable number (MPN) of total coliforms and thermotolerant microorganisms. For analysis, samples were plated on specific medium (Baird-Parker Agar Base himedia M043) and incubated at $37{ }^{\circ} \mathrm{C}$ for $24 \mathrm{~h}$. To Salmonella sp. detection was used plating the medium Salmonella Shigella agar. The presence of coliforms at $35^{\circ} \mathrm{C}$ was detected in all samples as well as $45^{\circ} \mathrm{C}$ except to first sample. To the pasteurized milk was found to coliforms at $35{ }^{\circ} \mathrm{C}$ and $45{ }^{\circ} \mathrm{C}$ in the second and third samples. Only in the second test was checked the presence of mesofilic bacteria. We have not found samples contaminated with microorganisms psychrotrophic, Salmonella sp. and Staphylococcus sp. According to the obtained results the quality of collected milk has unacceptable conditions of consumption compared to coliform counts, according to the parameters established by law.

Keywords:Coliform.Mesofilic Bacteria. Psicrotrofic Microorganisms. Salmoella. Staphylococcus

\section{QUALIDADE MICROBIOLÓGICA DE LEITE DE CABRA PRODUZIDO NO ESTADO DE ALAGOAS, BRASIL}

\begin{abstract}
RESUMO: O objetivo deste estudo foi verificar a qualidade microbiológica do leite de cabra cru e pasteurizado produzido no estado de Alagoas, Brasil. Foram realizadas três coletas intervaladas de amostras de leite de cabra cru e pasteurizado que foram levadas ao laboratório. Todas as amostras foram submetidas a contagem de microrganismos aeróbios mesófilos, microorganismos psicrotróficos, determinação do número mais provável (MPN) de coliformes totais e microorganismos termotolerantes. Para análise, as amostras foram plaqueadas em meio específico (BairdParker Agar Base himedia M043) e incubadas a $37^{\circ} \mathrm{C}$ durante 24h. Para Salmonella sp. A detecção foi utilizada plaqueando o meio Agar Salmonella Shigella. A presença de coliformes a $35^{\circ} \mathrm{C}$ foi detectada em todas as amostras, bem como em $45^{\circ} \mathrm{C}$, excepto na primeira amostra. Ao leite pasteurizado verificou-se coliformes a $35^{\circ} \mathrm{C}$ e $45^{\circ} \mathrm{C}$ na segunda e terceira amostras. Apenas no segundo teste foi verificada a presença de bactérias mesofílicas. Não foram encontradas amostras contaminadas com microorganismos psicrotróficos, Salmonella sp. E Staphylococcus sp. De acordo com os resultados obtidos, a qualidade do leite coletado apresenta condições de consumo inaceitáveis em relação às contagens de coliformes, de acordo com os parâmetros estabelecidos pela lei.
\end{abstract}

Palavras-chave: Coliformes. Bactérias mesofílicas. Micro-organismos psicotroficos. Salmonella, Staphylococcus.

\footnotetext{
${ }^{1}$ Universidade Federal de Alagoas

${ }^{2}$ Universidade Federal Rural de Pernambuco
} 


\section{INTRODUCTION}

The importance of goats as producers of meat and milk has been discussed and documented at the scientific literature for a long time (RUBINO et al,1999; BOYAZOGLU, MORAND- FEHR, 2011; HAENLEIN, 2004). HAENLEIN (2004) estimates that goat milk production should be higher than official statistical presented data because of the quantities of milk produced by small farms, especially in developing countries.

Brazil is the $15^{\text {th }}$ largest producer of goat milk in the world, accounting for $1.15 \%$ of world production (BRASIL, 2012), with the most herd concentrated in the Northeast region (91\%) producing $67 \%$ of goat milk (IBGE, 2006), but goat breeding has been of interest in the South and Southeast regions, especially for the milk market (JACOPINI et al, 2011).

Among the foods of animal origin, goat milk occupies a prominent place, due to its nutritional value. One of the characteristics is its digestibility. However, the use of milk by the organism is well conditioned to its quality, which is directly correlated to the hygiene conditions during its production (ALCÂNTARA, 1999).

In Brazil, quality parameters and production requirements of goat milk were published in Normative Instruction No. 37(BRASIL,2000). This legislation established the appropriate production conditions, hygiene procedures, storage and transport of raw and benefited milk, bacterial contamination standards for raw and processed milk, and standards for milk processing. Also, it establishes the need to adopt Good Manufacturing Practices (GMP) (BRASIL, 1977) by the manufacturing establishments of the product.

Milk, from the time of its production, is subject to a series of contaminations, mainly of microbial origin, in the milk or its derivatives. As result, there is a need to have proper milk supervision and control system. The sanitary control of food is an indispensable activity to the present society, in view of the possible distribution of disease-causing agents through then (OLIVEIRA, 2005). In according to Almeida et al (2016), main obstacles to the sanitary quality of milk are related to failures involving, principally, the management of milking and the absence of practices aimed at the adoption of good agricultural practices.

The importance of milk microorganisms reveals that knowledge about their microbial contamination index can be used in judging their intrinsic quality, as well as the sanitary conditions of their production and the health of the herd. Considering the potential of multiplying in raw milk, bacteria degrade fats, proteins and carbohydrates, making the product inappropriate for consumption and industrialization (COUSIN, 1982).

In pasteurized milk the microbiota depends on the microbial charge derived from the raw milk, the pasteurization efficiency, the extent of recontamination after thermal processing and the 
storage temperature (EGITO, PINHEIRO, FIGUEIREDO, 1989). Brazilian legislation allows the use of either pasteurization $\left(72-75^{\circ} \mathrm{C}\right.$ for $15-20$ seconds) or slow pasteurization $\left(62-65^{\circ} \mathrm{C}\right.$ for 30 minutes) for goat's milk (BRASIL, 2000).

Among the contaminating microorganisms of milk and derivatives, the thermotolerants, psychotrophic and coliform can be found. In view of the above, the objective of this study was to evaluate the microbiological quality of samples of raw and pasteurized goat milk, produced in the state of Alagoas, Brazil.

\section{MATERIAL AND METHOD}

Was conducted three collect of pasteurized and raw goat milk samples produced in Alagoas, Brazil. Five samples were collected, three of raw goat milk and two of pasteurized goat milk.

Were collected $500 \mathrm{~mL}$ from each group of milk using sterile flasks. The samples were transported in refrigerated boxes and taken to the Agricultural Microbiology Laboratory of Agricultural Sciences Center - Federal University of Alagoas, where the samples were stored under refrigeration and analyzed on the day of collection.

The preparation of the material laboratory used in bacteriological analysis process of samples passed all essential and necessary recommendations to ensure that the containers, instruments and glassware intended for contact with the milk to meet clean, sterile and free of residue when the analysis, thus preventing contamination of samples and obtaining an accurate result, comprising the recommendations described in the Compendium of the Microbiological Examination of foods (SPECK, 1976)

\section{SAMPLES HOMOGENIZATION AND DILUTION}

The diluent used for the analysis of milk was $0.1 \%$ peptone water. Thus, $25 \mathrm{~mL}$ milk sample (analytical unit) were diluted in $225 \mathrm{~mL}$ of $0.1 \%$ peptone water and then homogenized.

From the first dilution of the homogenized sample was transferred aseptically $1 \mathrm{~mL}$ to a flask containing $9 \mathrm{~mL}$ of peptone water $0.1 \%$ (dilution $10^{-2}$ ). The other dilutions made in the same way until you reach the last dilution $\left(10^{-3}\right)$.

\section{COUNT TOTAL MESOPHILIC AEROBIC MICROORGANISMS AND PSYCHROTROPHIC}

For this assay, diluted samples were inoculated in $1 \mathrm{~mL}$ of Standard Counting Agar (SCA) medium (dilutions $10^{-1}, 10^{-2}$ and $10^{-3)}$, in triplicate, scattered with Drigalski handle. After 
inoculation, the plates intended for mesophilic microorganisms count were incubated at $32{ }^{\circ} \mathrm{C}$ for 24 hours and for psychrotrophic microorganisms count the plates were incubated in a refrigerator for seven days at $11{ }^{\circ} \mathrm{C}$. All colonies observed were considered to counting, regardless of their color, shape and size. To count the plates with 30-300 Counting Formation Unit (CFU), were selected for the count of the colonies by multiplying the arithmetic mean of the same by the respective dilution factor and expressing the result in colony forming unit (CFU/10 $\left.{ }^{-1}\right)$.

\section{COUNT TOTAL AND FECAL COLIFORMS}

To determine the Most Probable Number (MPN) of total coliforms and termtolerantes microorganisms was used multiple tube technique, in triplicate, with an inverted Durhan tube inside according to the methodology described by the Brazilian Association of Technical Standards (ABNT, 1991).This technique comprises two distinct phases: the presumptive test, which recover the cells and detecting the presence of fermenting microorganisms of lactose and confirmatory test.

In the presumptive test selected three dilutions of the sample, namely, $10^{-1}, 10-^{2}$ and $10^{-3}$. With a sterile pipette $1 \mathrm{~mL}$ was inoculated in three sets of three tubes containing $9 \mathrm{~mL}$ Tryptone Lauryl Sulfate (TLS) medium and inverted Durham tube. The cultures were incubated at $37{ }^{\circ} \mathrm{C}$ for 48 hours. After incubation the evaluation was performed, the test being considered positive with obvious turbidity and gas production identified in the Durham tube.

In the confirmatory test, from each positive sample was performed sowing in test tubes containing an inverted Durham tube and Escherichia coli (E.C.) medium. The cultures were incubated at $44{ }^{\circ} \mathrm{C}$ and $24{ }^{\circ} \mathrm{C}$ for 48 hours, respectively. After incubation, the presence of coliform group was confirmed with gas production. Tubes with positive growth were recorded to determine the most probable number per milliliter $\left(\mathrm{NMP} / \mathrm{mL}^{-1}\right)$.

\section{PRESENCE OF STAPHYLOCOCCUS SP.}

To detect the presence of Staphylococcus sp. was inoculated $1 \mathrm{~mL}$ of each dilution into Petri dishes containing selective medium Baird Parker agar added Egg Yolk Emulsion (50\%), scattering with Drigalski handle and incubation at $37{ }^{\circ} \mathrm{C}$ for 24 hours. The Staphylococcus colonies were inoculated on plates containing Agar Chapman culture medium and incubated at 35 ${ }^{\circ} \mathrm{C}$ for 24 hours. Then, was observed the growth of the Staphylococcus sp. colonies, which was posteriorly inoculated in Nutrient Agar culture medium (NA). After this procedure, was carried out Gram staining protocol with the colonies. 


\section{PRESENCE OF SALMONELLA sp}

For the Salmonella sp. $1 \mathrm{ml}$ of the dilutions were inoculated into Petri dishes containing Salmonella Shigella Agar (SS) selective culture medium, the growth characteristic colony was isolated on Brilliant Green Agar, incubated at both $35^{\circ}$ for 24 hours. To further confirm the presence of Salmonella another test was conducted which was conducted from the characteristic colony growth between Three Sugars and Iron Agar (TSI) on slopes and incubated at $35^{\circ} \mathrm{C}$ for 24 hours.

\section{MICROBIOLOGICAL STANDARDS}

Microbiological standards were followed recommended in Normative Instruction No. 37 (BRAZIL, 2000) that determines the parameters of quality and goat milk production requirements.

\section{RESULTS AND DISCUSSION}

The presence of mesophilic aerobic bacteria was observed only for the second collection for fresh milk being obtained $3.30103 \log 10$. Normative Instruction $\mathrm{N}^{\mathrm{o}} 37$ does not provide limits for mesophilic microorganisms in raw milk type, but after pasteurization fixed value $\mathrm{M}=$ $4.69897 \log 10 \mathrm{~mL}^{-1}$. Therefore, within this context rated milk in all samples are within the required standards.

Mesophilic bacteria have the ability to grow at ambient temperature and are part of the milk microbial population, however its largest source of contamination is the environment and inadequate human manipulation. Besides being potentially pathogenic, also causes the degradation of lactose and acidification of milk by lactic acid buildup decreasing the quality of the product even after the thermic treatment.

In the second collect was detected the presence of coliforms at $35{ }^{\circ} \mathrm{C}$ in all raw milk samples, as well at $45{ }^{\circ} \mathrm{C}$, except the first collect (Figure 1). To the pasteurized milk was verified coliforms at $35^{\circ} \mathrm{C}$ and $45^{\circ} \mathrm{C}$ in second and third collect. 
Figure 1: Most Probable Number (MPN/mL-1) of coliforms at $30{ }^{\circ} \mathrm{C}$ and $45^{\circ} \mathrm{C}$ in the samples of raw and pasteurized goat milk collected in Alagoas state, Brazil.

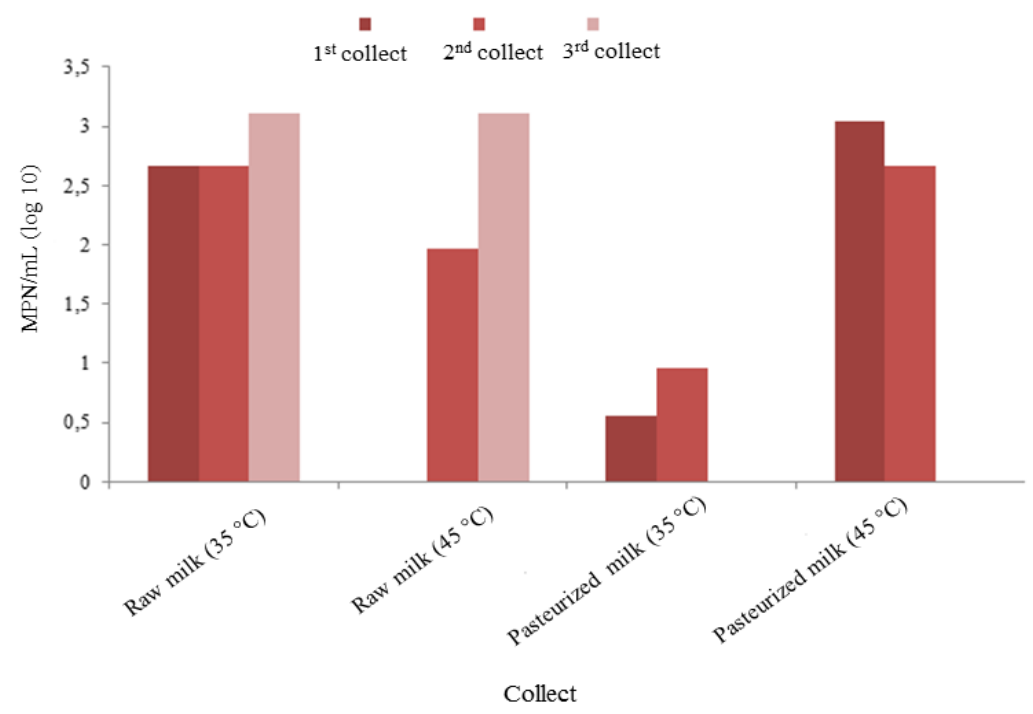

As for mesophilic microorganisms there are not standards of microbiological quality for coliform on raw milk. According to Normative Instruction $\mathrm{N}^{\mathbf{0}} 37^{(8)}$, the maximum value of coliforms at $35^{\circ} \mathrm{C}$ and $45^{\circ} \mathrm{C}$ in pasteurized milk is 4 and $1 \mathrm{MPN} / \mathrm{mL}^{-1}$ respectively. Santos et al (2009) shows that the count of psychrotrophic microorganisms in raw milk suffers interference to the storage time beyond the temperature.

The initial microbial charge is directly related to the cleanliness of the utensils used for milking and transportation of goat milk. Thus the cleaning of milking equipment and utensils are the main factors responsible for the production of high quality milk. It is estimated that $95 \%$ of problems with high bacterial counts are related to deficiencies in cleaning and sanitizing of utensils and the milking system and low hygiene (SANTOS, FONSECA, 2010).

Coliforms are destroyed in pasteurization, and the presence of these in milk show failures at some stage of the productive chain: overly contaminated raw material, inadequation industrial pasteurization and recontamination in the preheating section and the cooling section of the pasteurizer, inadequate transport conditions, inadequate distribution which allowed the survival and multiplication of such micro-organisms.

The results indicate the need for more effective action to control the manipulator and temperature of the pasteurizer, the selection of raw milk suppliers and sanitization equipment que come into contact with the milk after pasteurization. In according to Battaglini et al. (2013), the producer farms are small and characterized by animals of low production and few technification. The some authors affirm that the implantation of the practices of hygiene of milking, provides improved milk quality. 
Moraes et al. (2005) obtained similar results to analyze the microbiological quality of raw milk and found that in eight evaluated properties were found coliform in one of the three samples taken.

Catão, Ceballos (2001) analyzed raw and pasteurized milk found high counts for total and fecal coliforms, so that $33.33 \%$ of samples analyzed for total coliforms and $10 \%$ for fecal coliforms were in disagreement with the legislation.

Leite et al (2002) also found inadequate results for this group of microorganisms when analyzed pasteurized milk in the city of Salvador, Bahia, and found that, of the 20 samples analyzed, 13 (65\%) showed contamination by total coliforms, with values ranging from 0.60 to $3.38 \log \mathrm{MPN} / \mathrm{mL}^{-1}$, of which $11(55 \%)$ were at odds with the standards established by legislation. Instead, Souza et al (2013) found that pasteurization was effective to improve the microbiological quality of goat milk sold in the city of Alfenas-MG.

It is worth noting that the presence of coliforms at $45^{\circ} \mathrm{C}$ provide information on the occurrence of contamination of fecal origin and the likely presence of pathogenic microorganisms, as its main representative E. coli (2008).

No contaminated samples found with Salmonella and Staphylococcus sp, the results were consistent with the Foschino et al (2002) who analyzed the microbial composition of goat milk and observed that coliforms were constant components of the microbiota of raw milk, but no sample contained Salmonella sp.

\section{CONCLUSION}

In according to standards to microbiological quality of raw goat milk stablished by the legislation, the analyzed samples are out inappropriate to human consume.

The samples studied are in unacceptable conditions, with respect to coliform counts, according to the standards of identity and quality of pasteurized goat milk required by law.

\section{REFERENCES}

ABNT- Associação Brasileira De Normas E Técnicas. Bactérias coliformes totais, coliformes fecais e Escherichia coli em alimentos: determinação do número mais provávem (NMP) MB3463. Rio de Janeiro: ABNT, 1991.

ALCÂNTARA, M.D.B., Tecnologia Artesanal para Utilização do Leite de Cabra In: SOUZA, W.H., SANTOS, E.S. Criação de caprinos leiteiros: uma alternativa para o semi-árido. João Pessoa: EMEPA-PB, p. 173-190, 1999. 
ALMEIDA, A.C.et al. Perfil sanitário de unidades agrícolas familiares produtoras de leite cru e adequação à legislação vigente. Ciência Animal Brasileira, Goiânia, v. 17, n. 3, p. 303-315, jul/set. 2016. Disponível em

http://www.scielo.br/scielo.php?script=sci_abstract\&pid=S180968912016000300303\&lng=pt\&n $\mathrm{rm}=$ iso. Acesso em: mar. 2017

BATTAGLINI, A.P.P, Agnanni R, Dunga KS, Beloti V. Difusão de boas práticas e caracterização de propriedades leiteiras. Archivos de Zootecnia, n. 62, p.151-154, 2013.Available from: http://scielo.isciii.es/scielo.php?script=sci_arttext\&pid=S000405922013000100017. Acesso em: mar. 2017.

BOYAZOGLU, J., MORAND-FEHR, P. Mediterranean dairy sheep and goat products and their quality. A critical review. Small Ruminant Research, Amsterdam, v. 40, p. 1-11, 2001. Available from: http://dx.doi.org/10.1016/S0921-4488(00)00203-0. Acesso em: mar. 2017.

BRASIL. Ministério da agricultura, pecuária e do abastecimento - MAPA. Caprinos e ovinos. Brasília, DF, 2012.

BRASIL. Ministério da Agricultura, Pecuária e do Abastecimento. Instrução Normativa $n^{\circ} 37$ de 31 de outubro de 2000. Regulamento técnico de produção, identidade e qualidade de leite de cabra. Diário Oficial da União. Brasília, DF, 2000.

BRASIL. Ministério da Saúde. Agência Nacional de Vigilância Sanitária. Portaria no 326. Brasília, DF, 1977.

CATÃO, R.M.R., CEBALLOS, B.S.O. Listeria spp, coliformes totais e fecais e E. coli no leite cru e pasteurizado de uma indústria de laticínios no Estado da Paraíba (Brasil), Ciência e Tecnologia de Alimentos, n. 21, p.281-287. 2001.Disponível em http://dx.doi.org/10.1590/S0101-20612001000300006.

COUSIN, M.A., Presence and activity of psychrotrophic microrganisms in milk and dairy products: a review. Journal of Food Protection, v. 45, p. 172-207, 1982. Disponível em http://jfoodprotection.org/doi/pdf/10.4315/0362-028X-45.2.172?code=fopr-site. Acesso em: mar. 2017.

EGITO, A.S., PINHEIRO, R.R., FIGUEIREDO, E.A.P. Avaliação da pasteurização lenta do leite de cabra no controle de coliformes totais. Relatório Técnico do Centro Nacional Pesquisa de Caprino 1987-1995: EMBRAPA CNPC, N.12, 1989. Disponível: https://ainfo.cnptia.embrapa.br/digital/bitstream/item/124922/1/CNPC-1996-Avaliacao-da.pdf.

FOSCHINO, R.et al. Microbial composition, including the incidence of pathogens, of goats milk from the Bergamo region of Italy during a lactation year. Journal of Dairy Research, n 69, p. 213-225. 2002. Disponível em: https://www.ncbi.nlm.nih.gov/pubmed/12222800.

HAENLEIN, G.F.W. Goat milk in human nutrition. Small Ruminant Research, Amsterdam, n. 51, p. 155-163, 2004. Disponível em: doi:10.1016/j.smallrumres.2003.08.010

IBGE - Instituto brasileiro de geografia e estatística. Censo agropecuário, 2006. Available from: http://www.ibge.gov.br/home/estatistica/economia/agropecuaria/censoagro/2006/.

JACOPINI L.A.et al. Leite de Cabra: Características e qualidades. Revista ACTA Tecnológica, n.6, v.1, p. 169-180, 2011.Disponível em http://portaldeperiodicos.ifma.edu.br/index.php/actatecnologica/article/view/51.

LEITE, C.C.et al. Qualidade bacteriológica do leite integral (tipo C) comercializado em Salvador - Bahia. Revista Brasileira de Saúde, n.3, v.1, p. 21-25, 2002. Disponível em: http://revistas.ufba.br/index.php/rbspa/article/viewArticle/617. 
MORAES, C.R.et al. Qualidade microbiológica de leite cru produzido em cinco municípios do Estado do Rio Grande do Sul, Brasil. Acta Scientiae Veterinariae, n. 33, p. 259-264, 2005. Disponível: http://www.lume.ufrgs.br/handle/10183/20137.

OLIVEIRA, S.C.P.L., Características da Pasteurização do Leite de Cabra Adotada em miniusinas do Cariri Paraibano. Dissertação (Mestrado em Medicina Veterinária de pequenos ruminantes) Centro de Saúde e Tecnologia Rural. Universidade Federal de Campina Grande, 2005. Disponível em:

http://www.cstr.ufcg.edu.br/ppgmv/dissertacoes/dissertacoes/2005/suely_cristina_pereira_oliveir a.pdf.

PIETROWSKI, G.A.M.et al. Avaliação da Qualidade Microbiológica de Leite Pasteurizado Tipo C Comercializado na Cidade de Ponta Grossa-PR. In: VI Semana de Tecnologia em Alimentos. Universidade Tecnológica Federal do Paraná - UTFPR. Campus Ponta Grossa - Paraná - Brasil. Anais da VI Semana de Tecnologia em Alimentos. UTFPR. 2008.

RUBINO, R.et al.Typical products of the small ruminant sector and the factors affecting their quality. Small Ruminant Research, n. 34, p. 289- 302, 1999. Disponível em: http://dx.doi.org/10.1016/S0921-4488(99)00080-2

SANTOS, M.L., FONSECA, L.F.L. Qualidade microbiológica do leite: métodos de análise e estratégias de controle. 1st ed. São Paulo: Manole. 2010. 314p.

SANTOS, P.A.et al.. Efeito do tempo e da temperatura de refrigeração no desenvolvimento de microrganismos psicotróficos em leite cru refrigerado coletado na macrorregião de Goiânia, Go. Archivos de Zootecnia, n. 10, v. 4, p. 1237-1245, 2009 Disponíel em: http://revistas.bvsvet.org.br/cab/article/view/8543/8869

SOUZA, A.K. et al. Características microbiológicas e físico-químicas do leite de cabra submetido à pasteurização e ao congelamento, comercializado na cidade de Alfenas-MG. Revista da Universidade Vale do Rio Verde, n.11, v.1 p 224-233. 2013. Disponível em : http://dx.doi.org/10.5892/ruvrv.2013.111.224233

SPECK, M.L. Compendium for the microbiological examination of foods. 1st ed. Washington, D. C: American public health association, 1976, 701p 